\title{
WATER CONSUMPTION BY ANNUAL SWEET CLOVER PLANTS (PIVDENNY VARIETY) DEPENDING ON SOWING DATES AND RATES UNDER THE CONDITIONS OF THE SOUTHERN UKRAINIAN STEPPE
}

\author{
Shapar L.V. - PhD (Agriculture), Senior Researcher at the Department of Primary \\ and Elite Seed Production, \\ Institute of Irrigated Farming of the National Academy of Agrarian Sciences of Ukraine \\ Vlaschuk A.M. - PhD (Agriculture), Senior Researcher, Head of the Department \\ of Primary and Elite Seed Production, \\ Institute of Irrigated Farming of the National Academy of Agrarian Sciences of Ukraine \\ Misevich O.V. - PhD (Agriculture), Senior Researcher at the Department of Primary \\ and Elite Seed Production, \\ Institute of Irrigated Farming of the National Academy of Agrarian Sciences of Ukraine \\ Konashchuk O.P. - Senior Researcher at the Department of Primary \\ and Elite Seed Production, \\ Institute of Irrigated Farming of the National Academy of Agrarian Sciences of Ukraine
}

The article presents the results of research on the influence of sowing dates and sowing rates on water consumption by the Pivdenny variety of annual sweet clover plants. It has been established that in the conditions of the Southern Ukrainian steppe on dark chestnut soils it is impossible to obtain high crop seed yield without using the adjusted sowing dates and sowing rates. Improving moisture conditions and using optimal sowing dates and seeding rates we increase yields and reduce the water consumption by clover. The observations showed that the total water consumption varies depending on the time of sowing and sowing rates. It has been established that the water consumption by sweet clover plants, Pivdenny variety, depended on precipitation and reserves of productive moisture in the soil.

On average over the years of research, total water consumption from the $0-100 \mathrm{~cm}$ soil layer was $3094 \mathrm{~m}^{3} / \mathrm{ha}$ when sowing in the third ten-day period of March, $3182 \mathrm{~m}^{3} / \mathrm{ha}$ when sowing in the first ten-day period of April and $3278 \mathrm{~m}^{3} / \mathrm{ha}$ when sowing in the second ten-day period of April. Under such conditions moisture was most effectively used by plants in the first ten-day period of April, when the water consumption coefficient ranged from 463 to $490 \mathrm{~m}^{3} / \mathrm{c}$. Among the sowing dates considered, on average for the years of research, the maximum total water consumption of 3273-3283 $\mathrm{m}^{3} / \mathrm{ha}$ was on sowing in the second ten-day period of April, in this case the water consumption coefficient ranged from 502 to $670 \mathrm{~m}^{3} / \mathrm{c}$. The lowest total water consumption was $2127 \mathrm{~m}^{3} / \mathrm{ha}$ at the optimal sowing rate of 2.5 million units/ha. Among the sowing rates only in 2015 the total water consumption by sweet clover plants was $4387 \mathrm{~m}^{3} / \mathrm{ha}$ due to productive precipitation, its total amount for the entire growing season being $3153 \mathrm{~m}^{3} / \mathrm{ha}$, i.e. $315.3 \mathrm{~mm}$.

Summarizing the above results, we can conclude that the best yield of annual sweet clover, Pivdenny variety, was obtained when sowing in the first ten-day period of April at the sowing rate of 2.5 million units/ha. Thus, on average for 2015-2017 research, the maximum yield $(876.7 \mathrm{~kg} / \mathrm{ha}$ ) was obtained when sowing in the first ten-day period of April at sowing rates of 2.5 million units/ha. The favorable agro-climatic indicators in 2015 contributed to the annual sweet clover seed yield maximum value (1130 kg/ha) when sowing in the first ten-day period of April at sowing rates of 2.5 million units/ha.

Key words: sweet clover, variety, sowing date, sowing rate, seeds, yield.

Шапарь Л.В., Влащук А.М., Місєвич О.В., Конащук О.П. Водоспожсивання рослин буркуну білого однорічного сорту Південний залежно від строків сівби та норм висіву насіння в умовах Південного Степу Украӥни

У статті наведено результати досліджень впливу строків сівби та норм висіву насіння на водоспоживання рослин буркуну білого однорічного сорту Південний. Встановлено, щзо в умовах Південного Степу Украйни на темно-каштанових грунтах не можли- 
вим є отримання високої урожайності насіння культури без застосуванням коригованих строків сівби та норм висіву насіння. Поліпшення умов вологозабезпечення, використання оптимальних строків сівби та норм висіву сприяють підвищенню урожайності та зниженню коефіцієнту водоспоживання буркуну. Проведені спостереження показали, щз сумарне водоспоживання посівів культури змінюється залежно від строку сівби та норм висіву. Встановлено, що водоспоживання рослин буркуну білого сорту Південний відбувалося за рахунок атмосферних опадів та запасів продуктивної вологи із грунту.

У середньому за роки досліджень на посівах рослин із шару трунту 0-100 см сумарне водоспоживання складало $3094 \mathrm{~m}^{3} / 2$ а за сівби у третю декаду березня, $3182 \mathrm{~m}^{3} / 2 a-3 a$ сівби у першу декаду квітня $і 3278$ м $^{3}$ - за сівби у другу декаду квітня. В таких умовах найефективніше волога використовувалася рослинами у першу декаду квітня, коли коефіuієнт водоспоживання коливався від 463 до $490 \mathrm{~m}^{3} /$. . Серед досліджуваних строків сівби в середньому за роки досліджень максимальний показник сумарного водоспоживання

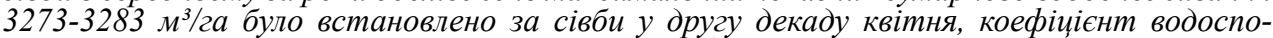
живання при изьому коливався від 502 до 670 м³.и. Найменше сумарне водоспоживання $2127 \mathrm{~m}^{3} / 2$ ба буо за оптимальної норми висіву 2,5 млн шт./га. Серед норм висіву насіння тільки у 2015 роия загальне сумарне водоспоживання рослин буркуну білого $4387 \mathrm{M}^{3} / 2 а$ було більшим за рахунок продуктивних опадів, загальна кількість яких за весь вегетаційний період культури становила $3153 \mathrm{M}^{3} / 2 a$, тобто 315,3 мм.

У середньому за 2015-2017 роки проведення досліджень максимальний показник урожайності - 876,7 кг/га отримано за сівби у периу декаду квітня за норми висіву 2,5 млн шт./га. За сприятливого за агрокліматичними показниками 2015 року урожайність насіння буркуну білого однорічного набула максимального значення - 1130 кг/га за сівби у першу декаду квітня за норми висіву 2,5 млн ит./га.

Ключові слова: буркун білий, сорт, строк сівби, норма висіву, насіння, урожайність.

Problem statement. Getting high yields of both winter and spring crops in the southern steppe of Ukraine is restrained by the availability of soil water, which is vital for physiological and growth processes that intensively affect the yields [1-5].

Annual sweet clover is a crop that makes full use of the spring-summer supply of soil moisture. To establish the total water consumption by sweet clover plants during the whole growing season, the reserves of productive moisture in the soil in the periods before sowing and before harvesting were determined, and the amount of precipitation for the entire growing season was added to them. It is known that the value of total water consumption is influenced by meteorological conditions, sowing density, agricultural technology, the field moisture content. That is why the indicators of total water consumption by the same crop in different areas at different sowing dates and sowing rates differ.

Analysis of recent research and publications. The water regime of the Ukrainian steppe soils belongs to the nonleaching type, its characteristic feature being a significant deficit of moisture during the entire growing season. Under such conditions, plants suffer more from insufficient moisture or drought than from other natural factors. Lack of moisture during the plant vegetation period leads to adverse changes in physiological processes, disruption of normal metabolism. During drought period in order to survive in extreme conditions, plants use soil moisture more economically, which causes a decrease in productivity because there is a direct relationship between crop yields and soil moisture levels. Therefore, in the steppe zone moisture is one of the main factors influencing seed yields $[6 ; 7]$.

Task setting. The task of the research was to study the water consumption by the Pivdenny variety annual sweet clover plants depending on the studied factors and their effect on seed productivity. The research was conducted in the experimental field at the Institute of Irrigated Farming, NAAS, in 2015-2017 in accordance with the requirements of generally accepted research methods complying with IPA 22 "Scientific basis of feed production, storage and use for obtaining competitive livestock products ("Feed and feed protein")" $[8 ; 9 ; 10 ; 11]$. 
The experiment covers two-factors and four-time repetition, it was carried out by split sites method, the placement of variants was randomized. The accounting area is $25 \mathrm{M}^{2}$. In the experiment we used the seeds of the Pivdenny variety annual sweet clover, the Institute of Irrigated Farming, NAAS, being the originator. According to the experiment scheme, the seeds of the annual sweet clover were sown in the first term (the third ten-day period of March); the second term (the first ten-day period of April) and the third term (the second ten-day period of April), at the sowing rates of 1.5-2.5-3.5 million units/ha.

Presentation of the main research material. The water consumption coefficient is one of the criteria for assessing the productivity of moisture use, which shows the amount of water consumed by plants for the formation of 1 centner of white clover seeds. Improving moisture conditions and using optimal sowing dates and seeding rates increase yields and reduce the water consumption by clover. The observations showed that the total water consumption varies depending on the time of sowing and sowing rates (table 1).

Table 1

Total water consumption by sweet clover plants, Pivdenny variety, depending on the timing of sowing from the soil layer of $0-100 \mathrm{~cm}, \mathrm{~m}^{3} / \mathrm{ha}$

\begin{tabular}{|c|c|c|c|c|c|c|}
\hline \multirow{3}{*}{$\begin{array}{l}\text { A factor, } \\
\text { sowing time }\end{array}$} & \multirow{3}{*}{ Year } & \multirow{3}{*}{$\begin{array}{c}\text { Total water } \\
\text { consumption, } \\
\mathbf{m}^{3} / \mathbf{h a}\end{array}$} & \multicolumn{4}{|c|}{ Moisture consumption, $\mathbf{m}^{3} / \mathbf{h a}$} \\
\hline & & & \multicolumn{2}{|c|}{ soil reserves } & \multicolumn{2}{|c|}{ precipitation } \\
\hline & & & $\mathrm{m}^{3} / \mathbf{h a}$ & $\%$ & $\mathrm{~m}^{3} / \mathrm{ha}$ & $\%$ \\
\hline \multirow{4}{*}{$\begin{array}{l}\text { Third ten-day } \\
\text { period of March }\end{array}$} & 2015 & 4278 & 1125 & 26 & 3153 & 74 \\
\hline & 2016 & 2982 & 1298 & 43 & 1684 & 57 \\
\hline & 2017 & 2021 & 1065 & 50 & 1065 & 50 \\
\hline & average & 3094 & 1163 & 40 & 1967 & 60 \\
\hline \multirow{4}{*}{$\begin{array}{l}\text { First ten-day } \\
\text { period of April }\end{array}$} & 2015 & 4433 & 1280 & 29 & 3153 & 71 \\
\hline & 2016 & 3008 & 1324 & 44 & 1684 & 56 \\
\hline & 2017 & 2106 & 1150 & 50 & 1150 & 50 \\
\hline & average & 3182 & 1251 & 40 & 1996 & 60 \\
\hline \multirow{4}{*}{$\begin{array}{l}\text { Second ten-day } \\
\text { period of April }\end{array}$} & 2015 & 4449 & 1296 & 29 & 3153 & 71 \\
\hline & 2016 & 3117 & 1434 & 46 & 1684 & 54 \\
\hline & 2017 & 2267 & 1311 & 50 & 1311 & 50 \\
\hline & average & 3278 & 1347 & 40 & 2049 & 60 \\
\hline
\end{tabular}

It has been established that the water consumption by sweet clover plants, Pivdenny variety, depended on precipitation and reserves of productive moisture in the soil. In the year of 2015 which was favorable for sweet clover as to the moisture reserves, the total water consumption was the greatest which subsequently resulted in the increase of seed productivity due to increased plant height, and leaf surface area. On average over the years of research, total water consumption from the $0-100 \mathrm{~cm}$ soil layer was $3094 \mathrm{~m}^{3} /$ ha when sowing in the third ten-day period of March, $3182 \mathrm{~m}^{3} /$ ha when sowing in the first ten-day period of April and $3278 \mathrm{~m}^{3} /$ ha when sowing in the second ten-day period of April.

The results obtained indicate that the total water consumption by plants was $53-74 \%$ dependent on the precipitation during the growing season. Under such conditions moisture was most effectively used by plants in the first ten-day period of April, when the water consumption coefficient ranged from 463 to $490 \mathrm{~m}^{3} / \mathrm{c}$ (table 2). 
Table 2

Water consumption by the Pivdenny variety sweet clover crop depending on sowing dates and sowing rates, average for 2015-2017

\begin{tabular}{|c|c|c|c|c|c|c|}
\hline $\begin{array}{c}\text { A factor, } \\
\text { sowing } \\
\text { time }\end{array}$ & $\begin{array}{c}\text { B factor, } \\
\text { sowing } \\
\text { rate, } \\
\text { mln } \\
\text { pc/ha }\end{array}$ & $\begin{array}{c}\text { Productive } \\
\text { moisture } \\
\text { reserve at } \\
\text { the time of } \\
\text { germination, } \\
\mathbf{m}^{3} / \mathbf{h a} \\
\end{array}$ & $\begin{array}{c}\text { Productive } \\
\text { moisture } \\
\text { reserve at } \\
\text { the time of } \\
\text { harvestingi, } \\
\mathbf{m}^{3} / \mathrm{ha} \\
\end{array}$ & $\begin{array}{c}\text { Precipitation } \\
\text { during the } \\
\text { vegetation } \\
\text { period, } \\
\text { m }^{3} / \mathrm{ha}\end{array}$ & $\begin{array}{c}\text { Total } \\
\text { water } \\
\text { consum- } \\
\text { ption, } \\
\text { m³/ha }\end{array}$ & $\begin{array}{c}\text { Water } \\
\text { consum- } \\
\text { ption } \\
\text { coefficient, } \\
\text { m }^{3} / \mathbf{c}\end{array}$ \\
\hline \multirow{3}{*}{$\begin{array}{l}3^{\text {rd }} \text { ten-day } \\
\text { period of } \\
\text { March }\end{array}$} & 1.5 & 1919 & 761 & 1931 & 3089 & 471 \\
\hline & 2.5 & 1919 & 758 & 1931 & 3092 & 438 \\
\hline & 3.5 & 1919 & 750 & 1931 & 3100 & 613 \\
\hline \multirow{3}{*}{$\begin{array}{l}1^{\text {st }} \text { ten-day } \\
\text { period of } \\
\text { April }\end{array}$} & 1.5 & 1994 & 746 & 1931 & 3179 & 436 \\
\hline & 2.5 & 1994 & 743 & 1931 & 3183 & 363 \\
\hline & 3.5 & 1994 & 740 & 1931 & 3186 & 490 \\
\hline \multirow{3}{*}{\begin{tabular}{|c}
$2^{\text {nd }}$ ten-day \\
period of \\
April \\
\end{tabular}} & 1.5 & 2089 & 747 & 1931 & 3273 & 561 \\
\hline & 2.5 & 2089 & 743 & 1931 & 3277 & 502 \\
\hline & 3.5 & 2089 & 737 & 1931 & 3283 & 670 \\
\hline
\end{tabular}

Among the sowing dates considered, on average for the years of research, the maximum total water consumption of $3273-3283 \mathrm{~m}^{3} / \mathrm{ha}$ was on sowing in the second ten-day period of April, in this case the water consumption coefficient ranged from 502 to $670 \mathrm{~m}^{3} / \mathrm{c}$. This is due to the fact that the rise of the above-zero air temperature and the availability of moisture caused an intensive growth of sweet clover plants. It was determined that on average for the 2015-2017 research, the productive soil moisture reserve was $1919-2089 \mathrm{~m}^{3} / \mathrm{ha}$ at the time of crop germination, which later resulted in obtaining high-grade shoots.

Among the sowing dates considered the moisture was most rationally used by sweet clover plants which were sown in the first ten-day period of April as evidenced by the water consumption coefficient of $363-490 \mathrm{~m}^{3} / \mathrm{c}$. The sowing rate also influenced the total water consumption of sweet clover plants (table 3 ).

The lowest total water consumption was $2127 \mathrm{~m}^{3} / \mathrm{ha}$ at the optimal sowing rate of 2.5 million units/ha. Greater number of sweet clover plants increased water consumption which resulted in higher total water consumption. Among the sowing rates only in 2015 the total water consumption by sweet clover plants was $4387 \mathrm{~m}^{3} /$ ha due to productive precipitation, its total amount for the entire growing season being $3153 \mathrm{~m} / \mathrm{ha}$, i.e. $315.3 \mathrm{~mm}$.

It should be noted that among the sowing rates under study, on average over the years of the research, the greatest use of productive moisture by sweet clover plants was from precipitation, its share making $44-72 \%$. The largest differences in the efficiency of productive moisture were observed in 2016 and 2017, when sweet clover plants used productive moisture from both soil reserves and precipitation $\left(44-56 \mathrm{~m}^{3} / \mathrm{ha}\right)$. The water consumption coefficient was also affected by sweet clover plant density. The lowest water consumption coefficient was with the optimal placement of plants per unit area, which contributed to the formation of the maximum sweet clover seed yield, which averaged $7.45 \mathrm{c} / \mathrm{ha}(745.5 \mathrm{~kg} / \mathrm{ha})$.

Summarizing the above results, we can conclude that the best yield of annual sweet clover, Pivdenny variety, was obtained on sowing in the first ten-day period of April at the sowing rate of 2.5 million units/ha. It should be noted that 2015 was the most favorable in terms of moisture, which ensured the subsequent highest seed productivity of sweet clover plants. 
Table 3

Total water consumption by the Pivdenny variety sweet clover plants from the soil layer of $0-100 \mathrm{~cm}$ depending on various sowing rates, $\mathrm{m}^{3} / \mathrm{ha}$

\begin{tabular}{|c|c|c|c|c|c|c|}
\hline \multirow{3}{*}{$\begin{array}{l}\text { B factor, sowing } \\
\text { rate, } \mathrm{mln} \mathrm{pc} / \mathrm{ha}\end{array}$} & \multirow{3}{*}{ Year } & \multirow{3}{*}{$\begin{array}{c}\text { Total water } \\
\text { consumption, } \mathbf{m}^{3} / \mathbf{h a}\end{array}$} & \multicolumn{4}{|c|}{ Moisture consumption, $\mathrm{m}^{3} / \mathrm{ha}$} \\
\hline & & & \multicolumn{2}{|c|}{ soil reserves } & \multicolumn{2}{|c|}{ precipitation } \\
\hline & & & $\mathrm{m}^{3} / \mathbf{h a}$ & $\%$ & $\mathrm{~m}^{3} / \mathrm{ha}$ & $\%$ \\
\hline \multirow{4}{*}{1.5} & 2015 & 4387 & 1233 & 28 & 3153 & 72 \\
\hline & 2016 & 3026 & 1342 & 44 & 1684 & 56 \\
\hline & 2017 & 2129 & 1175 & 55 & 956 & 45 \\
\hline & average & 3181 & 1250 & 42 & 1524 & 58 \\
\hline \multirow{4}{*}{2.5} & 2015 & 4387 & 1233 & 28 & 3153 & 72 \\
\hline & 2016 & 3038 & 1354 & 44 & 1684 & 56 \\
\hline & 2017 & 2127 & 1172 & 55 & 956 & 45 \\
\hline & average & 3184 & 1253 & 42 & 1524 & 58 \\
\hline \multirow{4}{*}{3.5} & 2015 & 4387 & 1228 & 28 & 3153 & 72 \\
\hline & 2016 & 3045 & 1340 & 44 & 1684 & 56 \\
\hline & 2017 & 2138 & 1176 & 55 & 956 & 45 \\
\hline & average & 3190 & 1248 & 42 & 1524 & 58 \\
\hline
\end{tabular}

Thus, on average for $2015-2017$ research, the maximum yield $(876.7 \mathrm{~kg} / \mathrm{ha})$ was obtained when sowing in the first ten-day period of April at sowing rates of 2.5 million units/ha. The favorable agro-climatic indicators in 2015 contributed to the annual sweet clover seed yield maximum value $(1130 \mathrm{~kg} / \mathrm{ha})$ when sowing in the first ten-day period of April at sowing rates of 2.5 million units/ha (table 4).

Table 4

Pivdenny variety annual sweet clover seed yield depending on the sowing dates and sowing rates

\begin{tabular}{|c|c|c|c|c|c|c|c|}
\hline \multirow{2}{*}{$\begin{array}{c}\text { A factor, sowing } \\
\text { time }\end{array}$} & \multirow{2}{*}{$\begin{array}{c}\text { B factor, } \\
\text { sowing } \\
\text { rate, } \\
\text { mln pc/ha }\end{array}$} & \multicolumn{4}{|c|}{ Yield, kg/ha } & \multicolumn{2}{|c|}{$\begin{array}{l}\text { Average for } \\
\text { factor, } \mathrm{kg} / \mathrm{ha}\end{array}$} \\
\hline & & 2015 & 2016 & 2017 & $\begin{array}{c}\text { Average for } \\
\text { 2015-2017 }\end{array}$ & $\mathbf{A}$ & B \\
\hline 1 & 2 & 3 & 4 & 5 & 6 & 7 & 8 \\
\hline \multirow{3}{*}{$\begin{array}{c}3^{\text {rd }} \text { ten-day period } \\
\text { of March }\end{array}$} & 1.5 & 840 & 790 & 340 & 656.67 & \multirow{3}{*}{623.33} & 656.67 \\
\hline & 2.5 & 900 & 830 & 390 & 706.67 & & 745.56 \\
\hline & 3.5 & 630 & 580 & 310 & 506.67 & & 548.89 \\
\hline \multirow{3}{*}{$\begin{array}{c}1^{\text {st }} \text { ten-day period } \\
\text { of April }\end{array}$} & 1.5 & 920 & 860 & 410 & 730.00 & \multirow{3}{*}{752.22} & \\
\hline & 2.5 & 1130 & 1010 & 490 & 876.67 & & \\
\hline & 3.5 & 850 & 720 & 380 & 650.00 & & \\
\hline \multirow{3}{*}{$\begin{array}{c}2^{\text {nd }} \text { ten-day period } \\
\text { of April }\end{array}$} & 1.5 & 790 & 670 & 290 & 583.33 & \multirow{3}{*}{575.56} & \\
\hline & 2.5 & 830 & 810 & 320 & 653.33 & & \\
\hline & 3.5 & 630 & 570 & 270 & 490.00 & & \\
\hline \multicolumn{8}{|c|}{ Assessment of partial differences significance } \\
\hline \multirow{2}{*}{ LED05, kg/ha } & $\mathrm{A}$ & 39.08 & 29.41 & 21.05 & 15.40 & & \\
\hline & $\mathrm{B}$ & 49.13 & 20.52 & 25.16 & 21.30 & & \\
\hline
\end{tabular}


Table 4 (Continued)

\begin{tabular}{|c|c|c|c|c|c|c|c|}
\hline & 2 & 3 & 4 & 5 & 6 & 7 & 8 \\
\hline \multicolumn{7}{|c|}{ Assessment of average main effects significance } \\
\hline \multirow{2}{*}{ LED05 kg/ha } & A & 22.56 & 16.98 & 12.15 & 8.90 & & \\
\hline & B & 28.36 & 11.85 & 12.58 & 12.30 & & \\
\hline \multicolumn{7}{|c|}{ Proportion of factor impact, \% } \\
\hline & A & 41.4 & 32.1 & 95.7 & 44.1 & & \\
\hline & B & 49.6 & 64.0 & 2.4 & 51.9 & & \\
\hline & AB & 5.7 & 3.1 & 1.1 & 2.9 & & \\
\hline
\end{tabular}

On average, by A factor, the maximum yield of $752.2 \mathrm{~kg} / \mathrm{ha}$ was achieved when sowing in the first ten-day period of April (fig. 1).

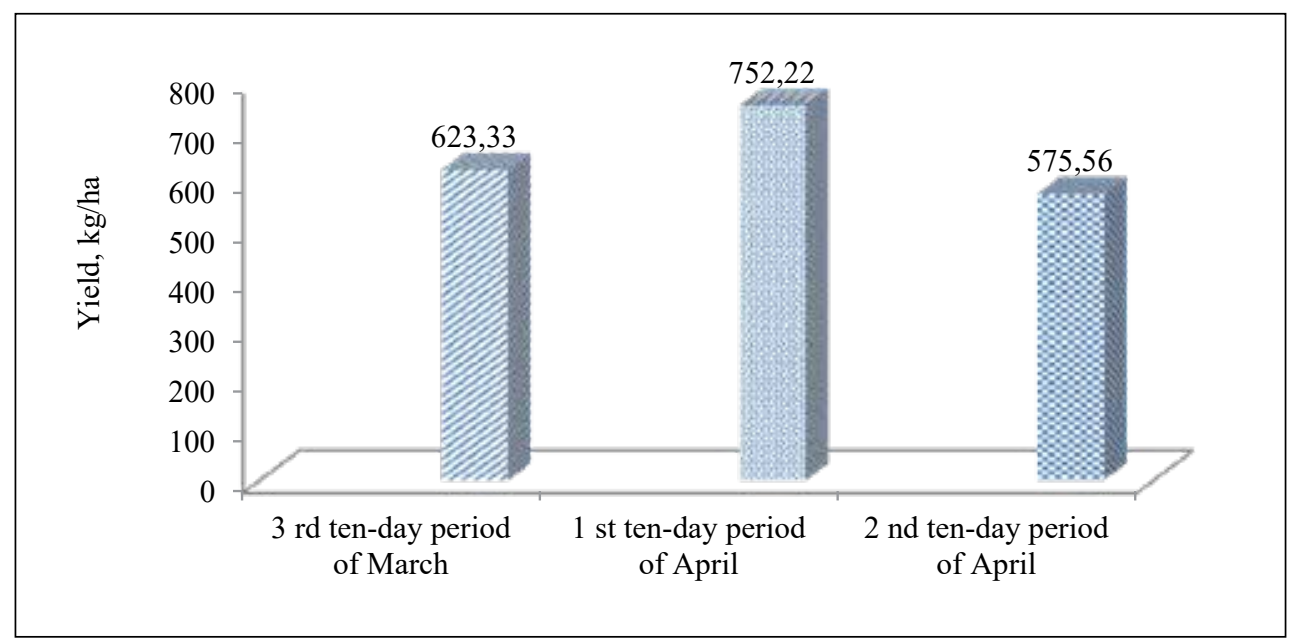

Fig. 1. Indicators of the Pivdenny variety sweet clover seed yield at different sowing dates, $\mathrm{kg} / \mathrm{ha}$ (average for 2015-2017)

Among the studied sowing rates the maximum seed yield of $745.5 \mathrm{~kg} / \mathrm{ha}$ was achieved at the sowing rate of 2.5 million units/ha (fig. 2).

On average, for 2015-2017 research, it was determined that, from a biological viewpoint, the best sowing time for growing sweet clover for seeds in the southern steppe of Ukraine is the first ten-day period of April at the sowing rate of 2.5 million units/ha.

Conclusions. Thus, we can conclude that under the Ukrainian southern steppe conditions on dark chestnut soils the seed productivity of annual sweet clover plants mainly depends on the meteorological conditions.

The research materials obtained show that the total water consumption by sweet clover plants depended mainly on the precipitation during the growing season (44-72\%). In such conditions, most effectively the moisture was used by crops sown in the second sowing period (the first ten-day period of April) when the water consumption coefficient ranged from 363 to $490 \mathrm{~m}^{3} / \mathrm{c}$. Therefore we can state that the Pivdenny variety sweet clover plants used soil moisture most effectively when sown in the first ten-day period of April at the sowing rate of 2.5 million units/ha. This cultivation method has prospects for its implementation on irrigated lands. 


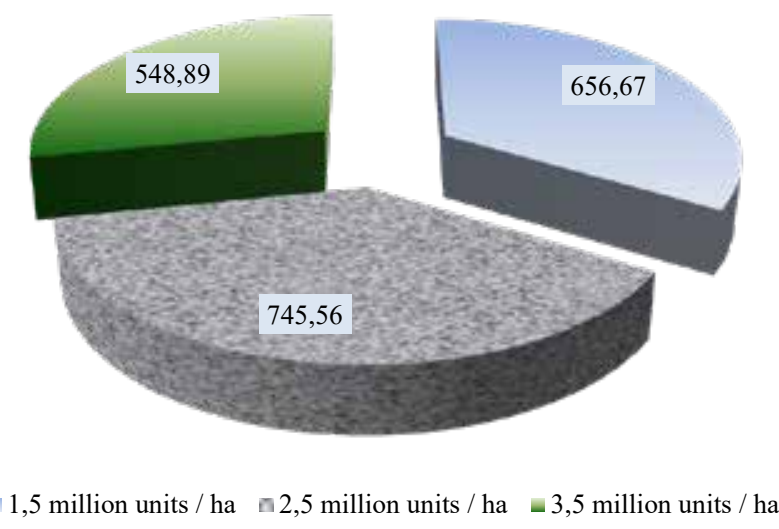

Fig. 2. Indicators of the Pivdenny variety sweet clover seed yield at different sowing rates, $\mathrm{kg} / \mathrm{ha}$ (average for 2015-2017)

\section{REFERENCES:}

1. Ушкаренко В.О. Зрошуване землеробство. Київ : Урожай, 1994. 328 с.

2. Роде А.А. Основы учения о почвенной влаге. Методы определения водного режима почв : монография. Ленинград : Гидрометиздат, 1969. 287 с.

3. Долгов С.И. Исследование подвижности почвенной влаги и ее доступности для растений. Москва : Изд. АН СССР, 1948. 206 с.

4. Заленский В.А. Водообеспеченность растений - важный фактор стабильности урожаев. Сельское хозяйство, 2005. № 6(38). С. 14-15.

5. Шевелуха В.С. Периодичность роста сельскохозяйственных растений и пути ее регулирования. Москва : Колос, 1980. 455 с.

6. Горбатенко А.І. Ефективність різних способів основного обробітку грунту під ярий ячмінь у зоні Степу : Бюл. Ін-ту зерн. госп-ва УААН. Дніпропетровськ, 2009. № 37. С. 12-14.

7. Срмолаєв М.М., Шиліна Л.І., Літвінов Д.В. Водний режим чорнозему типового в короткоротаційних зернових сівозмінах : зб. наук. праць Ін-ту землеробства УААН. Спецвипуск. 2002. С. 161-166.

8. Доспехов Б.А. Методика полевого опыта. Москва : Агропромиздат, 1985. $616 \mathrm{c}$.

9. Дисперсійний і кореляційний аналіз у землеробстві і рослинництві / Ушкаренко В.О., Нікішенко В.Л., Голобородько С.П., Коковіхін С.В. : навчальний посібник. Херсон : Айлант, 2008. С. 272-275.

10. Методика польових і лабораторних досліджень на зрошуваних землях / Р.А. Вожегова, Ю.О. Лавриненко, М.П. Малярчук [та ін.]. Херсон : Видавець Грінь Д.С., 2014. 285 с.

11. Основи наукових досліджень в агрономії / Єщенко В.О., Копитко П.Г., Опришко В.П., Костогриз П.В. Київ : Вид. Дія, 2005. 288 с. 